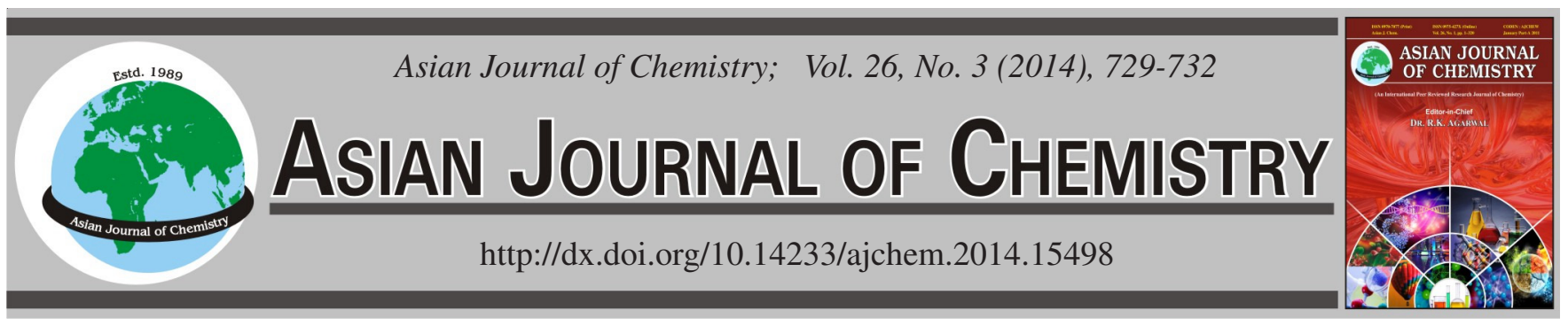

\title{
A Renewable Source of Bioenergy: Extraction, Spectral Characterization and Toxicological Studies with Microbial Screening on Indian Rubber (Hevea brasiliensis) Seed Oil
}

\author{
Sundaram Arvind Narayan ${ }^{1}$, Sivagnana Prabhu ${ }^{2, *}$, Sutha Shobana ${ }^{3}$ and Jeyaprakash Dharmaraja ${ }^{4}$
}

${ }^{1}$ Department of Mechanical Engineering, K.N.S.K. College of Engineering, Therekalputhoor-629 901, India

${ }^{2}$ Department of Mechanical Engineering, R.M.K. Engineering College, R.M.K. Nagar, Kavaraipettai-601 206, India

${ }^{3}$ Department of Chemistry, Rajas Institute of Technology for Women, Ozhuginasery, Nagercoil-629 001, India

${ }^{4}$ Division of Chemistry, Faculty of Science and Humanities, Sree Sowdambika College of Engineering, Aruppukottai-626 134, India

*Corresponding author: E-mail: kksprmk@gmail.com; shobanasubam@gmail.com

Received: 18 March 2013;

Accepted: 24 July 2013;

Published online: 30 January 2014;

AJC-14623

\begin{abstract}
The present study is carried out to find the extraction, physico-chemical analysis and toxicology with in vitro microbial screening characters of the Indian rubber seed oil. Vibrational studies of the oil exemplify the characteristic strong absorption at 1741 and $1461 \mathrm{~cm}^{-1}$ for $-\mathrm{C}=\mathrm{O}$ and $-\mathrm{C}=\mathrm{C}$ - groups respectively and did not give any idea about the presence of cyanide peak. Both the ${ }^{1} \mathrm{H}$ NMR and ${ }^{13} \mathrm{C}$ NMR spectral studies specify that the presence of triacylglycerol groups were saturated in addition to unsaturated. Determination of cyanide by means of colorimetric method was verified and there is no any absorption observed. This can be attributed that no hazardous linamarin were found in Indian rubber seed oil. Further, to estimate the potential of alternative hosts for oil production and influence of this oil with some common pathogenic microorganisms were also screened by well-diffusion techniques.
\end{abstract}

Keywords: Rubber seed oil, Physico-chemical parameters, Linamarin, Microbial screening.

\section{INTRODUCTION}

In recent times, focusing on developing alternative and renewable sources of liquid fuels that are environmentally friendly ${ }^{1}$. The growing population of equally the developing and developed nations and the consequential enhance in their diesel consumption and the non-renewability of diesel source (petroleum), over and above the unpleasant environmental belongings of diesel burning are a few of the factors that has made alternatives to petroleum diesel good-looking ${ }^{2}$. Biodiesel blends can be used in most compression-ignition (diesel) engines with little or no modifications ${ }^{3,4}$.

Several toxicological studies were carried out on the rubber seed and its oil. From literature, Hevea brasilensis rubber seed contains cyanide content. It is found out that the level of cyanide concentration decreased drastically on drying. In recent times, production of rubber seed oil (RSO) shows a huge raise in both quantity and quality in Asia, due to its significant role in different industrial processes. Indian rubber seed oil is yellow in colour with a semi-drying oil feature. It does not comprise any unusual fatty acids and its rich source of vital fatty acids $\left(\mathrm{C}_{18: 2}\right.$ and $\left.\mathrm{C}_{18: 3}\right)$ composed upto $51.87 \%$ of its total fatty acids content ${ }^{5}$. The toxin element in the seeds of rubber is linamarin which is a cyanogenic glucoside ${ }^{6,7}$. The molar mass and density is $247.25 \mathrm{~g} \mathrm{~mol}^{-1}$ and $1.43 \mathrm{~g} \mathrm{~cm}^{-3}$, respectively.
The hydrolysis or cyanogensis of linamarin by endogenous enzyme namely linamarase ( $\beta$-glucosidase), results in the formation of glucose and acetone cyanohydrin, which later on decomposes into hydrogen cyanide and acetone ${ }^{8,9}$. The molecular structure of linamarin is shown in Fig. 1.<smiles>CC(C)(C#N)OC1OC(O)C(O)C(O)C1O</smiles>

Fig. 1. Structure of linamarin (m.f. $\mathrm{C}_{10} \mathrm{H}_{17} \mathrm{NO}_{6}$ )

In this investigation, extraction, physico-chemical parameters, the optimization process of the rubber seed (Hevea brasiliensis) to attain good quality oil ${ }^{10}$ and analyze the toxin of linamarin in the Indian rubber seed oil by using different solvents extraction namely $n$-hexane, ethanol and chloroformmethanol mixture were carried out. The spectroscopic (FTIR, ${ }^{1} \mathrm{H}$ NMR and ${ }^{13} \mathrm{C} \mathrm{NMR}$ ) analysis and colorimetric method based on the Konig reaction were also carried out. In addition, microbial screening characters of Indian rubber seed oil were also evaluated. 


\section{EXPERIMENTAL}

Rubber seeds were obtained from the Rubber Research Institute, Kottayam (Kerala). All chemicals used in this study were analytical grade and used without further purification. The acid value, percentage free fatty acids (FFAs), iodine value, saponification value, unsaponifiable matter of the Indian rubber seed oil were determined according to Association of Official Analytical Chemists (AOCS). Fatty acid compositions of the semi oil was determined using gas chromatography techniques and were performed on Shimadzu gas chromatograph equipped with flame ionization detector and capillary column (30 $\mathrm{m} \times 0.25 \mathrm{~mm} \times 0.25 \mu \mathrm{m}$ films). The detector temperature was programmed for $280{ }^{\circ} \mathrm{C}$ with flow rate of $0.3 \mathrm{~mL} / \mathrm{min}$ and the injector temperature was set at $250{ }^{\circ} \mathrm{C}$. Nitrogen gas was used as the carrier gas. Microorganisms were obtained from the stock culture of Central Drugs Laboratory, Kolkata; Indian Institute of Chemical Biology, Kolkata and Mycology and Plant Pathology Laboratory, Calcutta University, Kolkata, India. FTIR of the product was recorded on a JASCO FT/ IR-410 spectrophotometer in the range $4000-400 \mathrm{~cm}^{-1}$ using $\mathrm{KBr}$ disk. Both ${ }^{1} \mathrm{H}$ and ${ }^{13} \mathrm{C}$ NMR of the ROS oil was recorded on Perkin Elmer-32 spectrometer analysis using the solvent $\mathrm{CDCl}_{3}$.

General procedure: Damaged seeds were cleaned, shelled and dried at $108{ }^{\circ} \mathrm{C}$ for $26 \mathrm{~min}$. The seed and its kernel are full of about 638 and $749 \mathrm{mg} \mathrm{HCN}$ per $\mathrm{Kg}$. It is reported that storage at room temperature for atleast period of 2 months is effectual in plummeting the $\mathrm{HCN}$ content ${ }^{6}$. The seeds were shelled and dried in the oven upto $102^{\circ} \mathrm{C}$ for near $50 \mathrm{~min}$ it is the initial process, the final optimization process is given in Scheme-I and the Table-1 (Fig. 2) shows that the removal of $\mathrm{CN}(\%)$ from rubber seed throughout drying. The seeds were reserved in the refrigerator The rubber seeds were crushed using the grinder. Indian rubber seed oil was extracted from the $500 \mathrm{~g}$ rubber seeds by Soxhlet extractor using $n$-hexane as solvent at $60^{\circ} \mathrm{C}$ for $6 \mathrm{~h}$. It was dried over anhydrous sodiumsulphate and the solvent removed by rotary evaporation.
TABLE-1

REMOVAL OF CN (\%) FROM RUBBER SEED DURING DRYING

\begin{tabular}{cccccc}
\hline \multirow{2}{*}{$\begin{array}{c}\text { Time } \\
(\min )\end{array}$} & 69 & 102 & 123 & 144 & 166 \\
\cline { 2 - 6 } & 6.10 & 20.33 & 23.71 & 30.91 & 29.06 \\
\hline 25 & 15.20 & 24.67 & 31.43 & 34.69 & 32.61 \\
50 & 21.32 & 27.74 & 32.98 & 34.79 & 33.76 \\
75 & 24.44 & 23.07 & 33.90 & 37.62 & 35.61 \\
100 & 27.11 & 34.39 & 33.07 & 34.11 & 41.00 \\
125 & 29.12 & 42.09 & 34.51 & 34.69 & 42.61 \\
150 & & & & & \\
\hline
\end{tabular}

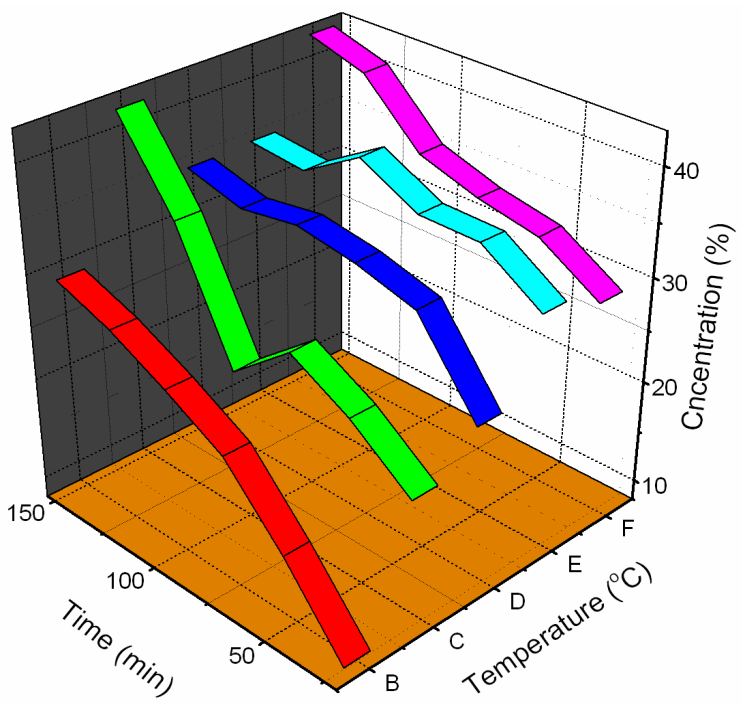

Fig. 2. Graphical Representation of the concentration of $\mathrm{CN}(\%)$ from rubber seed with temperature (where $\mathrm{B}=069^{\circ} \mathrm{C} ; \mathrm{C}=102{ }^{\circ} \mathrm{C} ; \mathrm{D}$ $\left.=123{ }^{\circ} \mathrm{C} ; \mathrm{E}=144{ }^{\circ} \mathrm{C} ; \mathrm{F}=166^{\circ} \mathrm{C}\right)$

\section{RESULTS AND DISCUSSION}

The physico-chemical properties of Indian rubber seed oil such as colour, free fatty acid \%, acid value, saponification value, iodine value and unsaponifiable matter were determined $^{11,12}$. Fuel properties were determined according to the AOCS (1980), procedures for the following properties i.e.,

$80^{\circ} \mathrm{C}$

(i) Rubber Seed (Different size) Residue (I) + Polysaccharides (EtOH Soluble)

$\mathrm{EtOH} / 25 \mathrm{~min}$

$$
\begin{aligned}
& \text { Residue (I) } \underset{\mathrm{H}_{2} \mathrm{O} / 2.5 \mathrm{Hrs}}{\stackrel{90^{\circ} \mathrm{C}}{\longrightarrow}} \text { Residue (II) + Polysac charides }\left(\mathrm{H}_{2} \mathrm{O} \text { Soluble }\right)
\end{aligned}
$$

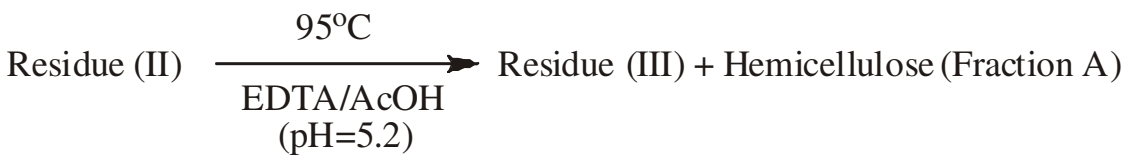

$$
\begin{aligned}
& \text { Residue (III) } \underset{10 \% \mathrm{NaOH}}{\stackrel{85^{\circ} \mathrm{C}}{3 \text { Vol.EtOH }}} \text { Hemicellulose (Fraction B) + Cellulose } \\
& \text { (2Hrs) } \\
& \text { Below } 100^{\circ} \mathrm{C}
\end{aligned}
$$

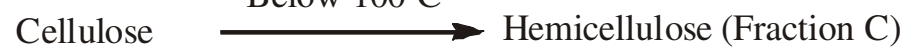

Scheme-I: Methodology for final optimization process of rubber seed oil 
refractive index, specific gravity, viscosity, cloud point, fire point, ash content, iodine value, peroxide value and acid value. The refractive index and specific gravity were measured at 30 and $40{ }^{\circ} \mathrm{C}$, respectively. The kinematic viscosity was determined using a Ferrantic portable viscometer at $30^{\circ} \mathrm{C}$. Cetane index was calculated according to Klopfenstein and Walker ${ }^{13}$.

Fatty acid composition of seed oil was determined using gas chromatography (GC). About $0.1 \mathrm{~mL}$ oil was changed to methyl ester using $1 \mathrm{~mL} \mathrm{NaOMe}(1 \mathrm{M})$ in $1 \mathrm{~mL}$ hexane before being injected into the gas chromatograph. A GC analysis was performed on a Shimadzu gas chromatograph equipped with flam ionization detector and capillary column $(30 \mathrm{~m} \times 0.25 \mathrm{~mm}$ $\times 0.25 \mu \mathrm{m}$ films). The detector temperature was programmed for $280{ }^{\circ} \mathrm{C}$ with flow rate of $0.3 \mathrm{~mL} / \mathrm{min}$. The injector temperature was set at $252{ }^{\circ} \mathrm{C}$. Nitrogen was used as the carrier gas. Identification of the peaks was performed by comparing retention times with those of genuine standards analyzed under the same conditions. The solid fat content decreased as temperature improved. Solid fat content was steady for temperatures above $15^{\circ} \mathrm{C}$. At low temperatures, solid fat content was far above the ground in Indian rubber seed oil, probably because it had low saturated fatty acid and high unsaturated fatty acid contents.

Fatty acid composition of seed oil was determined using gas chromatography. About $0.1 \mathrm{~mL}$ oil was changed to methyl ester using $1 \mathrm{~mL} \mathrm{NaOMe}(1 \mathrm{M})$ in $1 \mathrm{~mL}$ hexane before being injected into the gas chromatograph. A GC analysis was performed on a Shimadzu gas chromatograph equipped with flame ionization detector and capillary column $(30 \mathrm{~m} \times 0.25$ $\mathrm{mm} \times 0.25 \mu \mathrm{m}$ films $)$. The detector temperature was programmed for $280{ }^{\circ} \mathrm{C}$ with flow rate of $0.3 \mathrm{~mL} / \mathrm{min}$. The injector temperature was set at $252^{\circ} \mathrm{C}$. Nitrogen was used as the carrier gas. Identification of the peaks was performed by comparing retention times with those of genuine standards analyzed under the same conditions. The solid fat content decreased as temperature improved. Solid fat content was steady for temperatures above $15{ }^{\circ} \mathrm{C}$. At low temperatures, solid fat content was far above the ground in Indian rubber seed oil, probably because it had low saturated fatty acid and high unsaturated fatty acid contents.

Vibrational (FTIR) spectroscopy performing the major peaks and their functional groups of the Indian rubber seed oil showed characteristic strong absorption bands ${ }^{11,12,14}$ at 1741 $\mathrm{cm}^{-1}$ for the ester carbonyl $(-\mathrm{C}=\mathrm{O})$ functional groups. ${ }^{1} \mathrm{H}$ NMR spectroscopy showing the principal signal assignments of Indian rubber seed oil produced ${ }^{11,12}$, the ${ }^{1} \mathrm{H}$ NMR spectrum of Indian rubber seed oil: $0.73-0.77 \mathrm{ppm}$ of terminal $\left(-\mathrm{CH}_{3}\right), 1.11-$ $1.16 \mathrm{ppm}$ of methylene protons $\left(-\mathrm{CH}_{2}-\right), 1.86-1.91 \mathrm{ppm}$ for the protons $\alpha$ to the carbonyl groups $\left(-\mathrm{CH}_{2}-\mathrm{C}-\right), 2.61-2.69$ ppm for diallylic methylene $\left(-\mathrm{C}=\mathrm{C}-\mathrm{CH}_{2}-\mathrm{C}=\mathrm{C}-\right.$ ) and $4.17 \mathrm{ppm}$ of protons in $\alpha$ and $\beta$ position in glyceryl $1^{11,12} \cdot{ }^{13} \mathrm{C}$ NMR, also viewing the main signal assignments of the Indian rubber seed oil, indicated the presence of allylic carbon atoms at $26.9 \mathrm{ppm}$, methylene carbon atoms at 26.9-29.9 ppm, glyceryl carbon atoms at 61.9-68.8 ppm, olefinic carbon atoms at 128-129.6 ppm) and carbonyl carbon atoms at 172.31-177 ppm.

The Indian rubber seed oil which was studied in this method was extracted using $n$-hexane as a solvent. The commercial cyanide was used as a standard and was compared with Indian rubber seed oil which was extracted using $n$-hexane. The determination of cyanide confirmed no response of the cyanide in Indian rubber seed oil and did not show any colour comparing with commercial cyanide which observed blue colour. The result reinforces the vibrational data that no cyanide observed in this measurement. The commercial cyanide showed high response $\mathrm{e}^{7,15}$ at $633 \mathrm{~nm}$. The colorimetric method based on Konig reaction showed no response for the detection of cyanide in the Indian rubber seed oil. The response of cyanide and Indian rubber seed oil are shown in Fig. 3.

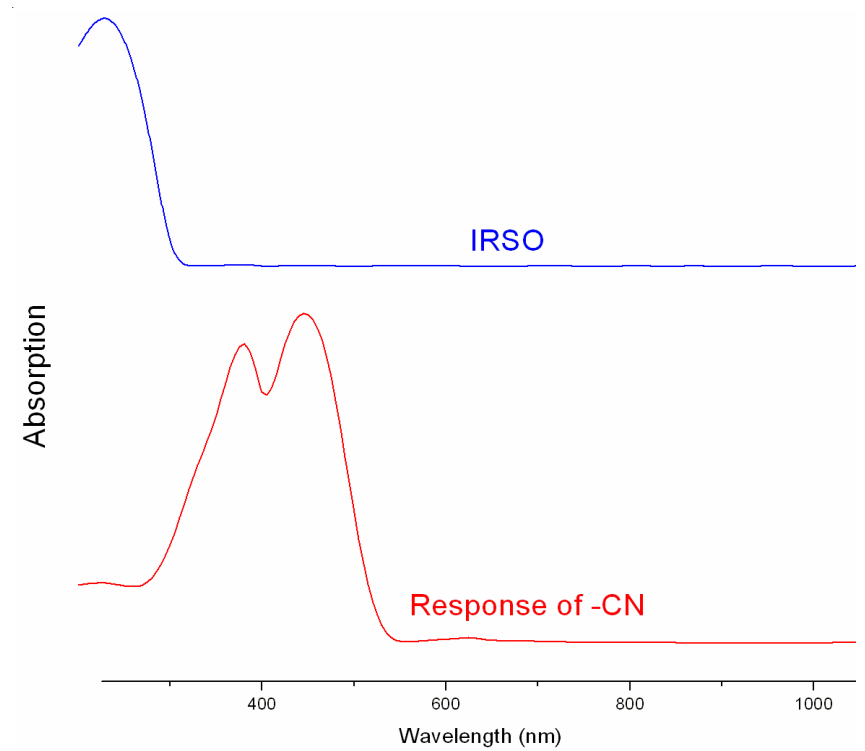

Fig. 3. Colorimetric absorption of Indian rubber seed oil and commercial cyanide compound

Captivatingly, lots of the lipid extracts had antimicrobial activities ${ }^{16}$. The antimicrobial activity of the Indian rubber seed oil was studied by the disc diffusion method on agar against various micro-organisms. In the case of solutions with a low activity, so far, a large concentration or volume is attractive. Because of the partial capacity of discs, holes or cylinders are somewhat used ${ }^{17}$. The Indian rubber seed oil at a concentration of $500 \mu \mathrm{g} / \mathrm{mL}$ and $750 \mu \mathrm{g} / \mathrm{mL}$ exhibited notable $(p<0.051)$ antimicrobial effect against all the tested microorganisms. The extract showed study antibacterial activity against Candida sonorensis, Escherichia coli, Lactobacillus brevis, Pachhysolen tannophilus, Pichia guilliremondii, Saccharomyces cerevisiae and Zymomonas mobilis. Although, their activity against Pichia guilliremondii was found to be extensively $(p>0.089)$ less than the control. The antimicrobial activity was compared with the standard chloramphenicol at a concentration of $10 \mu \mathrm{g} / \mathrm{mL}$ (Fig. 4). All treatments were performed in triplicate and each data point in the results is the mean of two or three replicate tests. All experiments were repeated at least once.

\section{Conclusion}

The current study has revealed that no functional groups such as cyanide $(-\mathrm{CN})$ is associated with linamarin being observed. We reasoned that since rubber seed falls at the peak of the rainy season, imbibitions of water by the seed might make active a lot of enzymes especially lipase and linamarase. During the August break, we plucked rubber seeds from the trees and dried them at $63{ }^{\circ} \mathrm{C}$ for $45 \mathrm{~h}$. This process inactivated 


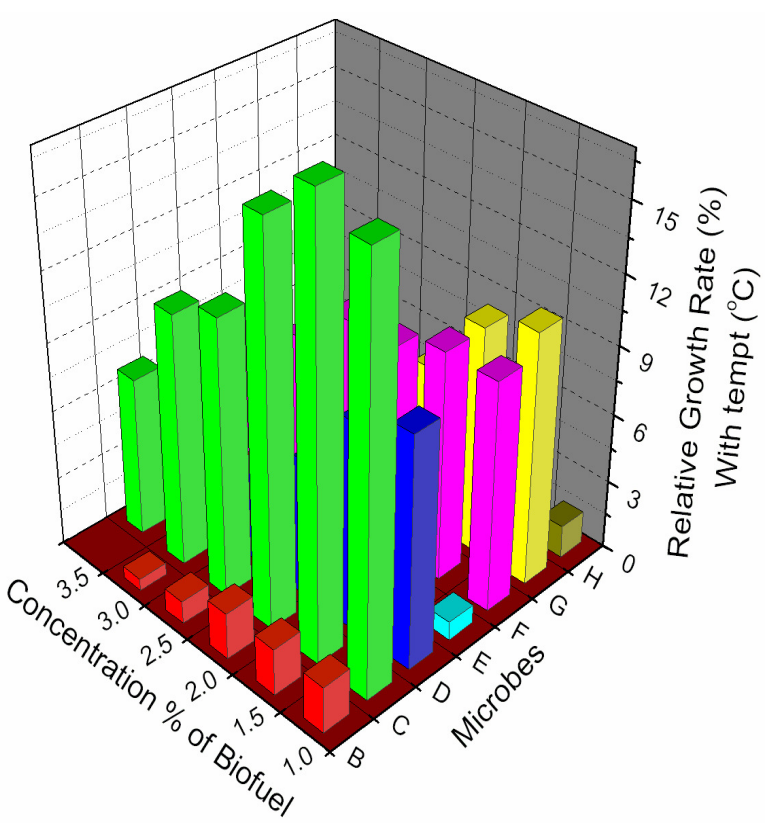

Fig. 4. Microbial screening of Indian rubber seed oil (where $\mathrm{B}=$ Escherichia coli $; \mathrm{C}=$ Lactobacillus brevis; $\mathrm{D}=$ Zymomonas mobilis; $\mathrm{E}=$ Pichia guilliremondii $; \mathrm{F}=$ Saccharomyces cerevisiae $; \mathrm{G}=$ Pacchysolen tanno philus $; \mathrm{H}=$ Candida sonorensis)

the enzymes and rendered the seed industrially viable. We conclude that the methanol extract of Indian rubber seed oil had significant in vitro lipid antimicrobial activity.

\section{ACKNOWLEDGEMENTS}

The authors dedicated this paper to our beloved late Professors Dr. T.C. Manohar and K. Natesan, Department of
Chemistry and Research Centre, South Travancore, Hindu College, Nagercoil, India. Thanks are also due to STIC, CUSAT, Cochin, India for providing the analytical facilities.

\section{REFERENCES}

1. T.Y. Leng, A.R. Mohamed and S. Bhatia, Can. J. Chem. Eng., 77, 156 (1999).

2. S. Shah, S. Sharma and M.N. Gupta, Energy Fuels, 18, 154 (2004).

3. S.A. Narayan, S. Shobana, A. Sundaram and J. Dharmaraja, Int. J. Recent Technol. Eng., 1, 143 (2013).

4. S.A. Narayan and S. Shobana, Int. J. Sci. Mod. Eng., 1, 18 (2013).

5. V.M. Gandhi, K.M. Cherian and M.J. Mulky, J. Am. Oil Chem. Soc., 67, 883 (1990).

6. B.M. Abdullah and J. Salimon, Asian J. Biochem., 5, 33 (2010).

7. S.A. Narayan, S. Shobana, S.M. Swamy and J. Dharmaraja, National Conference on Advanced Materials Processing Characterization and Applications (NCAMPA-2013), p. 240 (2013).

8. C.A. Idibie, H. David and S.E. Iyuke, Biol. Biosyst. Eng., 30, 261 (2007).

9. S. Sornyotha, K. Kyu and K. Ratanakhanokchai, Food Chem., 104, 1750 (2007)

10. A.I. Aigbodion and C.K.S. Pillai, Progr. Org. Coat., 38, 187 (2000).

11. S.A. Narayan, K.K.S. Prabhu, S. Shobana and J. Dharmaraja, International Conference on Perspectives in Vibrational Spectroscopy (ICOPVS-2013), p. 99 (2013).

12. S.A. Narayan, K.K.S. Prabhu, S. Shobana and J. Dharmaraja, International Conference on Impact of Climate Change on Food, Energy \& Environment (ICCFEE-2013), p. 121 (2013).

13. W.E. Klopfenstein and H.S. Walker, J. Am. Oil Chem. Soc., 60, 1596 (1983).

14. G. Gelbard, O. Bres, R.M. Vargas, F. Vielfaure and U. Schuchardt, J. Am. Oil Chem. Soc., 72, 1239 (1995).

15. K.K.W. Mak, H. Yanase and R. Renneberg, Biosens. Bioelectron., 20, 2581 (2005).

16. Y. Rajeshwar, R. Ahmed, A.S. Sunder, J. Devilal, M. Gupta and P. Mazumder, Iran. J. Pharmacol. Therap., 7, 67 (2008).

17. A. Bartner, K.P. Pfeiffer and H. Batner, Pharmazie, 49, 512 (1994). 